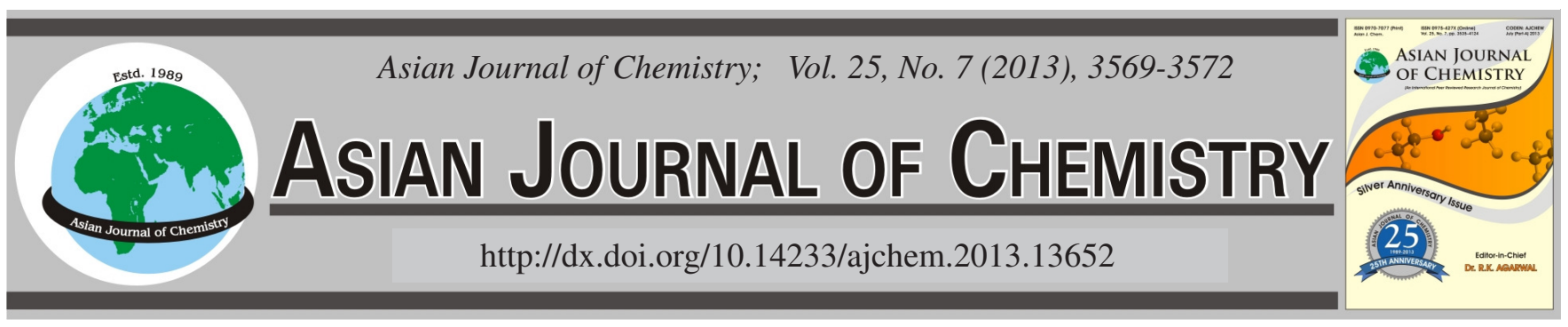

\title{
Spectrophotometric Study of the Biocoordination Chemistry of Strontium Nitrate and Glutathione
}

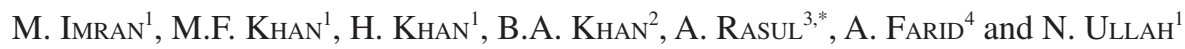

\begin{abstract}
${ }^{1}$ Department of Pharmaceutical Chemistry, Faculty of Pharmacy, Gomal University, Dera Ismail Khan, Pakistan
${ }^{2}$ Department of Pharmaceutics, Faculty of Pharmacy, Gomal University, Dera Ismail Khan, Pakistan

${ }^{3}$ Department of Pharmacy, Faculty of Pharmacy \& Alternative Medicine, The Islamia University of Bahawalpur, Bahawalpur, Pakistan

${ }^{4}$ Gomal Center of Biochemistry and Biotechnology, Gomal University, Dera Ismail Khan, Pakistan
\end{abstract}

*Corresponding author: E-mail: dr.akhtarstar@gmail.com

\begin{abstract}
The effect of strontium nitrate on the status of glutathione in aqueous media was examined spectrophotometrically. The wavelength of $412 \mathrm{~nm}$ was used for the determination of thiol concentration in samples in accordance with a well known Elman's method. During the experiments the $\mathrm{pH}$ was maintained at 7.6 by phosphate buffer which was proposed to be suitable for performing in vitro experiments on thiols by Evans. When glutathione was exposed to different concentrations of strontium nitrate in aqueous solution, there was a significant decrease in the concentration of glutathione which means that strontium nitrate causes chemical modulation of glutathione and converts this molecule to its oxidized or disulfide form or glutathione-strontium complex. Time dependent, temperature and $\mathrm{pH}$ effect of strontium nitrate on the chemical status of glutathione was also examined. It was observed that there was a decrease in concentration of glutathione with these parameters. This study was carried out in in vitro condition to establish the model of in vivo reaction. The exact mechanism of reaction between metal and glutathione still need to be investigated but formation of strontium-glutathione complex may be proposed.
\end{abstract}

Key Words: Strontium nitrate, 5,5-Dithiobis,2,nitrobenzoic acid, Ellman's method, Glutathione.

\section{INTRODUCTION}

Glutathione (GSH) is one of the main non protein tripeptide thiol-compounds in mammalian-cells and has bio-reducing activity $^{1}$. Inside the cells, GSH is present in two forms i.e., reduced state (GSH) and oxidized state (GSSG). Inside cells glutathione is present in reduced state (GSH) and is more than $95 \%$ of the total (GSH + GSSG) content. Intra-cellular oxidized glutathione (GSSG) is present in small quantity but may increase with oxidative-stress or pathological-conditions and reduced glutathione depletion occurs at the same time ${ }^{2}$. GSH and GSSG act as a thiol redox-couple and have role in gene regulation and intra-cellular signal transduction ${ }^{3}$. Glutathione in reduced state (GSH) has important roles in cell division, immuneresponse, signal processes control, programmed cell-death, some xenobiotics and heavy metals detoxification ${ }^{4,5}$. Glutathione has antioxidant activity and a cofactor for enzymatic reactions that need readily available electron pairs ${ }^{6}$. Glutathione is very reactive from physico-chemical point of view and conjugate to other molecules including the heavy metal ions because of its sulfhydryl moiety ${ }^{7,8}$. GSH/GSSG ratio gives an early indication of oxidative stress or risk of disease ${ }^{2}$. Metals toxicity includes geno-toxicity or carcinogenicity, neuro-toxicity ${ }^{9}$ and this reaction with GSH has attracted the attention of biomedical scientists.

In present study the effect of strontium nitrate on the chemical status has investigated spectrophotometicaly in aqueous medium of strontium nitrate on the metabolism of biologically active molecules like glutathione. Therefore it was of interest to see the chemical effect of this metal strontium nitrate on the chemical and metabolic status of glutathione in aqueous solution.

\section{EXPERIMENTAL}

L-Glutathione (GSH) (Fluka), strontium nitrate (Merck), 5,5-dithiobis,2-nitrobenzoic acid (DTNB) (Sigma), sodium hydroxide (Fluka AG), potassium dihydrogen phosphate (Merck), $\mathrm{HCl} 37$ \% (Kolch light), distilled water (double distilled). UV/visible 1601 spectrophotometer: (Shimadzu), pH Meter: NOV-210 (Nova scientific company Ltd. Korea), Oven: Memmert Model U-30,854 Schwabach (Germany), Magnetic stirrer (England), hot plate: 400 (England), sensitive weighing balance, Sortorius. Micoropipettes (200, 500 and $1000 \mu \mathrm{L}$ ) Socorex Swiss (Finland). 


\section{RESULTS AND DISCUSSION}

Effect of different concentration $(0.0001,0.001,0.01$, $0.1,1,2 \mathrm{mM}$ ) of strontium nitrate on the chemical status of glutathione $(\mathbf{1} \mathbf{~ m M}): 2 \mathrm{~mL}$ of different concentrations $(0.0001,0.001,0.01,0.1,1,2 \mathrm{mM})$ of strontium nitrate solutions were added separately to $2 \mathrm{~mL}$ of $1.0 \mathrm{mM}$ glutathione taken in six separate test tubes, shaked well. Final concentration of glutathione in each of the above test tube was $0.50 \mathrm{mM}$ $(500 \mu \mathrm{M})$ and that of strontium nitrate were $0.00005 \mathrm{mM}(0.05$ $\mu \mathrm{M}), 0.0005 \mathrm{mM}(0.5 \mu \mathrm{M}), 0.005 \mathrm{mM}(5 \mu \mathrm{M}), 0.05 \mathrm{mM}(50$ $\mu \mathrm{M}), 0.5 \mathrm{mM}(500 \mu \mathrm{M})$ and $1 \mathrm{mM}(1000 \mu \mathrm{M})$, respectively.

$0.2 \mathrm{~mL}$ from each one of the above test tubes was taken followed by the addition of $2.3 \mathrm{~mL}$ of phosphate buffer $\mathrm{pH}$ 7.6 and $0.5 \mathrm{~mL}$ of $1 \mathrm{mM}$ DTNB solution. The final concentration of glutathione in the test tubes was $0.03333 \mathrm{mM}(33.33$ $\mu \mathrm{M})$ and of strontium nitrate were $0.000003 \mathrm{mM}(0.003 \mu \mathrm{M})$, $0.00003 \mathrm{mM}(0.03 \mu \mathrm{M}), 0.0003 \mathrm{mM}(0.33 \mu \mathrm{M}), 0.003 \mathrm{mM}$ $(3.33 \mu \mathrm{M}), 0.0333 \mathrm{mM}(33.33 \mu \mathrm{M})$ and $0.06666 \mathrm{mM}(66.66$ $\mu \mathrm{M})$, respectively.

Control solution (glutathione blank) containing $2 \mathrm{~mL}$ of $1 \mathrm{mM}$ glutathione solution and $2 \mathrm{~mL}$ of phosphate buffer having $\mathrm{pH}$ of 7.6 was added. The final concentration of glutathione in control solution (glutathione blank) was also $0.5 \mathrm{mM}(500 \mu \mathrm{M})$, as in the sample. $0.2 \mathrm{~mL}$ was taken from this sample and add to it $2.3 \mathrm{~mL}$ of phosphate buffer $\mathrm{pH}$. 7.6 followed by the addition of $0.5 \mathrm{~mL}$ of $(1 \mathrm{mM})$ DTNB. The ultimate concentration of glutathione in control sample will be $0.03333 \mathrm{mM}(33.33 \mu \mathrm{M})$.

The absorbences were taken after $5 \mathrm{~min}$ at $412 \mathrm{~nm}$ against reference cell containing $2.8 \mathrm{~mL}$ phosphate buffer $\mathrm{pH} 7.6$ and $0.2 \mathrm{~mL}$ of $1 \mathrm{mM}$ glutathione solution. The effect of strontium nitrate on the chemical status of glutathione was studied in terms of determination of the absorbences which were then converted into concentration of glutathione in mixtures by a well known Elman's method ${ }^{10}$. The concentrations of glutathione (determined from the glutathione standard curve) left after treatment with strontium nitrate was plotted against the concentration of strontium nitrate in mixture samples (Fig. 1).

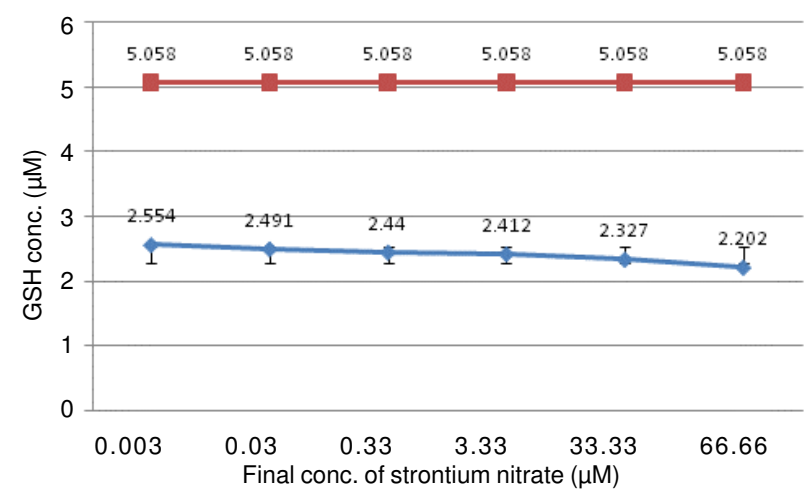

Fig. 1. Effect of different concentration of $\mathrm{Sr}\left(\mathrm{NO}_{3}\right)_{2}$ on the status of GSH. - Control GSH (without metal). $\triangle \mathrm{Sr}\left(\mathrm{NO}_{3}\right)_{2}+\mathrm{GSH}(0.003-66.66)$ $\mu \mathrm{M}$. Results are the mean $\pm \mathrm{SE}$ of 3 experiments

Effect of different concentration $(0.0001,0.001,0.01$, $0.1,1$ and $2 \mathrm{mM}$ ) of strontium nitrate on the chemical status of glutathione $(\mathbf{1 ~} \mathbf{~ m M})$ with time: $2 \mathrm{~mL}$ of different concentrations $(0.0001,0.001,0.01,0.1,1$ and $2 \mathrm{mM}$ ) of strontium nitrate solutions were added to $2 \mathrm{~mL}$ of $1 \mathrm{mM}$ glutathione and the chemical status of GSH was examined.

The absorbences were noted at 0, 20, 40, 60, 90 and 120 min and the concentration of glutathione (determined from the glutathione standard curve) left after treatment with strontium nitrate was plotted against the time interval and are shown in Figs. 2-6.

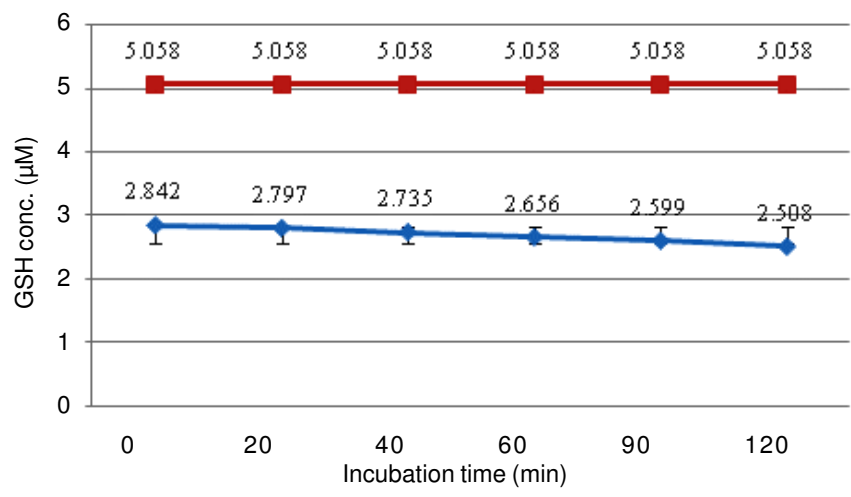

Fig. 2. Effect of strontium nitrate $(0.003 \mu \mathrm{M})$ with time, incubation period (0-120 min). Control GSH (without metal). $\triangle \mathrm{Sr}\left(\mathrm{NO}_{3}\right)_{2}+\mathrm{GSH}$. Results are the mean \pm SE of 3 experiments

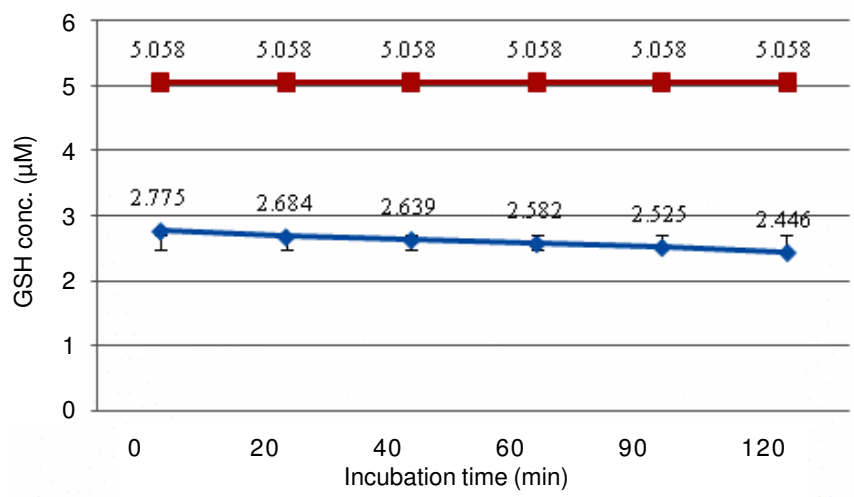

Fig. 3. Effect of strontium nitrate $(0.03 \mu \mathrm{M})$ with time, incubation period (0-120 min). Control GSH (without metal). $\mathrm{Sr}\left(\mathrm{NO}_{3}\right)_{2}+\mathrm{GSH}$. Results are the mean \pm SE of 3 experiments

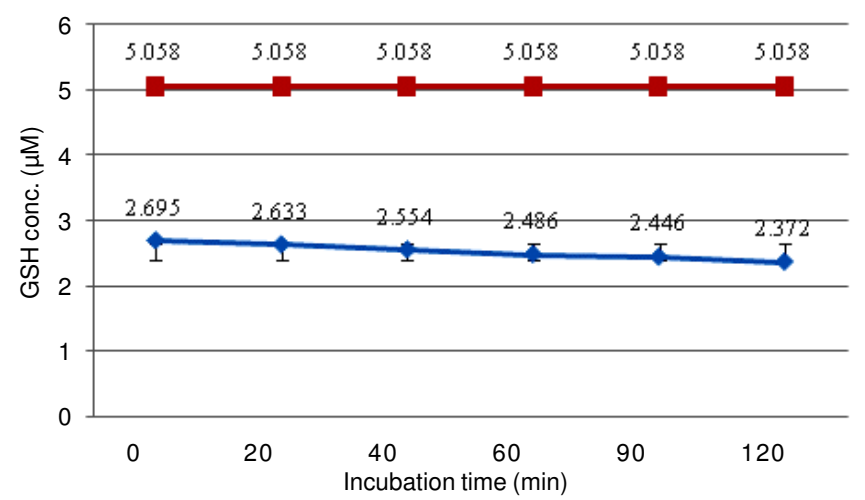

Fig. 4. Effect of strontium nitrate $(0.33 \mu \mathrm{M})$ with time, incubation period $(0-120 \mathrm{~min})$. Control GSH (without metal). $\rightarrow \mathrm{Sr}\left(\mathrm{NO}_{3}\right)_{2}+\mathrm{GSH}$. Results are the mean \pm SE of 3 experiments 


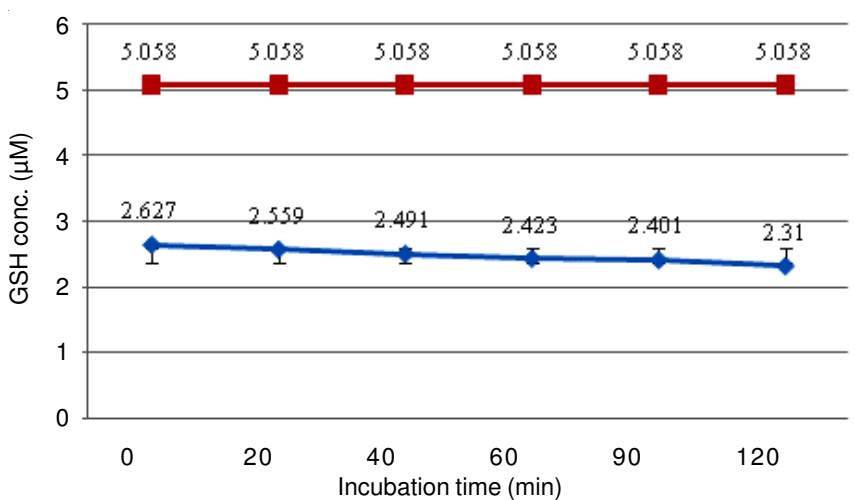

Fig. 5. Effect of strontium nitrate $(3.33 \mu \mathrm{M})$ with time, incubation period (0-120 min). Control GSH (without metal). $\left.\mathrm{Sr}_{(\mathrm{NO}}\right)_{2}+\mathrm{GSH}$. Results are the mean \pm SE of 3 experiments

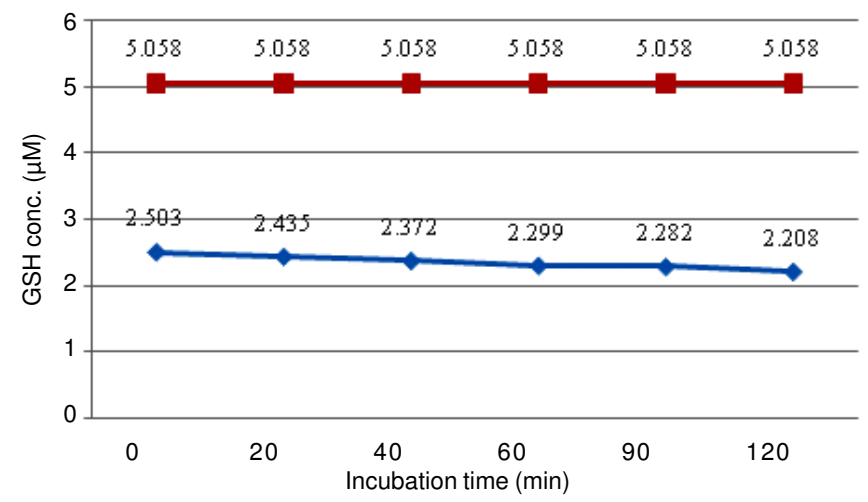

Fig. 6. Effect of strontium nitrate $(66.66 \mu \mathrm{M})$ with time, incubation period (0-120 min). Control GSH (without metal). $\mathrm{Sr}\left(\mathrm{NO}_{3}\right)_{2}+\mathrm{GSH}$. Results are the mean \pm SE of 3 experiments

Effect of different pH $(6.5,7.5,8.5,9.0,9.5,10)$ buffer on the chemical status of glutathione solution in the absence and presence of strontium nitrate: $2 \mathrm{~mL}$ of $1 \mathrm{mM}$ glutathione was mixed with $2 \mathrm{~mL}$ of $1 \mathrm{mM}$ strontium nitrate in test tube. Shake well and left for $5 \mathrm{~min}$. The final concentration of glutathione and strontium nitrate in reaction mixture was calculated to be $0.5 \mathrm{mM}(500 \mu \mathrm{M})$. Sample cuvettes were prepared by taking $0.2 \mathrm{~mL}$ from above mixture in six test tube separately and $2.3 \mathrm{~mL}$ of each buffer solution having $\mathrm{pH}$ $(6.5,7.5,8.5,9.0,9.5,10)$ was added in six test tube, followed by the addition of $0.5 \mathrm{~mL}$ of $1 \mathrm{mM}$ DTNB. The final concentration of glutathione and strontium nitrate in sample mixture was $0.03333 \mathrm{mM}(33.33 \mu \mathrm{M})$. Control solution was prepared by mixing $2 \mathrm{~mL}$ of $1 \mathrm{mM}$ glutathione and $2 \mathrm{~mL}$ of each buffer solution having $\mathrm{pH}(6.5,7.5,8.5,9.0,9.5,10)$ separately. Left for $5 \mathrm{~min}, 0.2 \mathrm{~mL}$ from above mixture was taken and mixed with $2.3 \mathrm{~mL}$ of each buffer solution having $\mathrm{pH}(6.5,7.5,8.5$, $9.0,9.5,10)$ followed by the addition of $0.5 \mathrm{~mL}$ of $1 \mathrm{mM}$ DTNB.

Absorbencies were taken after $5 \mathrm{~min}$ at $412 \mathrm{~nm}$ against reference cell containing $2.8 \mathrm{~mL}$ of respective phosphate buffer $\mathrm{pH}(6.5,7.5,8.5,9.0,9.5,10)$ and $0.2 \mathrm{~mL}$ of $1 \mathrm{mM}$ gluta-thione. The effect of strontium nitrate on the chemical status of glutathione in different $\mathrm{pH}(6.5,7.5,8.5,9.0,9.5,10)$ buffer was studied in terms of determination of the absorbencies which were then converted into concentration of glutathione in mixtures by a well known Elman's method ${ }^{10}$, as mentioned in standard curve for glutathione. Finally, the concentrations of glutathione (determined from the glutathione standard curve) left after treatment with strontium nitrate was plotted against the final concentration of strontium nitrate in mixture samples (Fig. 7).

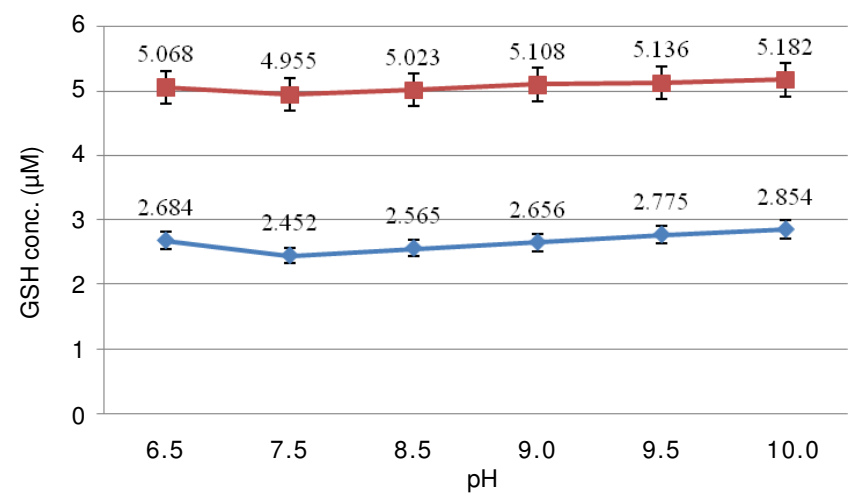

Fig. 7. Effect of strontium nitrate $(27.3 \mu \mathrm{M})$ on GSH $(27.3 \mu \mathrm{M})$. $\mathbf{\square}$ Control $\mathrm{GSH}$ (without metal). $\mathrm{Sr}\left(\mathrm{NO}_{3}\right)_{2}+\mathrm{GSH}$. Results are the mean \pm SE of 3 experiments

Effect of different temperature (at 25,35 and $45^{\circ} \mathrm{C}$ ) on the chemical status of glutathione $(0.1 \mathrm{mM}): 2 \mathrm{~mL}$ of $0.1 \mathrm{mM}$ strontium nitrate solution was added separately to $2 \mathrm{~mL}$ of $0.1 \mathrm{mM}$ glutathione taken in three separate test tubes, shacked well. These test tubes were kept in water bath for 10 min to maintain the temperature of $\left(25,35\right.$ and $\left.45^{\circ} \mathrm{C}\right)$. Final concentration of glutathione and strontium nitrate in each of the above test tube was $0.05(50 \mu \mathrm{M})$, respectively.

Samples cuvettes were prepared by taking $0.2 \mathrm{~mL}$ of strontium nitrate plus glutathione mixture from each one of the previously made test tubes and diluted with $2.3 \mathrm{~mL}$ of phosphate buffer $\mathrm{pH} 7.6$ and then $0.5 \mathrm{~mL}$ of $1 \mathrm{mM}$ DTNB stock solution was added in to each test tube. The final concentration of glutathione and strontium nitrate in the sample test tubes was $0.0033 \mathrm{mM}(3.33 \mu \mathrm{M})$, respectively.

Control solution (glutathione blank) for glutathione was also prepared by taking $2 \mathrm{~mL}$ of $0.1 \mathrm{mM}$ glutathione stock solution in a test tube to which $2 \mathrm{~mL}$ of phosphate buffer having $\mathrm{pH}$ of 7.6 was added. The final concentration of glutathione in control solution (glutathione blank) was also $0.05 \mathrm{mM}$ $(50 \mu \mathrm{M})$ as in the sample. $0.2 \mathrm{~mL}$ was taken from this sample and add to it $2.3 \mathrm{~mL}$ of phosphate buffer $\mathrm{pH}$. 7.6 followed by the addition of $0.5 \mathrm{~mL}$ of $(1 \mathrm{mM})$ DTNB. The ultimate concentration of glutathione in control sample will be $0.0033 \mathrm{mM}$ (3.33 $\mu \mathrm{M})$.

Absorbences were taken after $5 \mathrm{~min}$ at $412 \mathrm{~nm}$ against reference cell containing $2.8 \mathrm{~mL}$ phosphate buffer $\mathrm{pH} 7.6$ and $0.2 \mathrm{~mL}$ of $0.1 \mathrm{mM}$ glutathione solution. The effect of strontium nitrate on the chemical status of glutathione at different temperature was studied in terms of determination of the absorbences which were then converted into concentration of glutathione in mixtures by a well known Elman's method, as mentioned in standard curve for glutathione. Finally the concentrations of glutathione (determined from the glutathione standard curve) left after treatment with strontium nitrate was plotted against the final concentration of strontium nitrate in mixture samples (Fig. 8). 


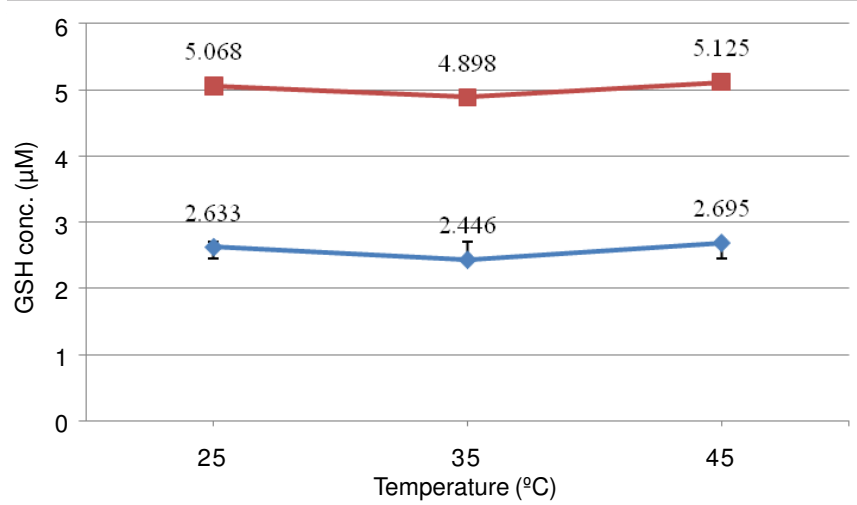

Fig. 8. Effect of strontium nitrate $(3.33 \mu \mathrm{M})$ on $\mathrm{GSH}(3.33 \mu \mathrm{M})$. $\mathbf{a}$ Control GSH (without metal). $\checkmark \mathrm{Sr}\left(\mathrm{NO}_{3}\right)_{2}+\mathrm{GSH}$. Results are the mean \pm SE of 3 experiments

Glutathione (GSH) is an endogenously produced tripeptide thiol, which plays key role in intra and extra cellular antioxidants defense ${ }^{11}$. Glutathione has several interesting and important physiological chemical, pharmacological and toxicological implications, which suggest the role of GSH in the detoxification of electrophile, metabolite of chemicals or/and drugs $^{12}$.

Strontium has many biological uses and is used to treat patients suffering from meta static prostate cancer ${ }^{13}$, osteoporosis ${ }^{14}$, as an anti-allergic ${ }^{15}$ and to prevent dental caries $^{17}$. As GSH can undergo oxidation, so GSH acts as electron donor ${ }^{18}$.

Since GSH and strontium metal have many important pharmacological and biological uses, so it was interesting to investigate the interaction between GSH and strontium metal. There are reports on the interaction of divalent $\mathrm{Sr}^{2+}$ ion with thiol (SH) group ${ }^{19}$.

The effect of strontium nitrate, on the status of reduced glutathione (GSH) in aqueous media was examined spectrophotometrically. Study performed suggests that as the concentration of strontium nitrate increases GSH concentration decreases, when interaction time between GSH and metal increases, concentration of GSH also decreases.

Maximum interaction between GSH and metal was observed at $\mathrm{pH}$ of 7.5 and temperature of $35^{\circ} \mathrm{C}$. The results of present study indicated that there might have some interaction between strontium metal and GSH but the exact mechanism of action of strontium nitrate on GSH metabolic status in this study is not known. However there are two proposed possibilities of conversion of GSH by strontium nitrate to: Conversion of reduced glutathione (GSH) to oxidized form GSSG. Conversion of GSH to strontium-glutathione complex Sr-SG.

Such proposed reaction can be written in equation form as follow.

$$
\begin{gathered}
\mathrm{Sr}^{2+}+2 \mathrm{GSH} \longrightarrow \mathrm{Sr}(\mathrm{SG})_{2} \\
\mathrm{Sr}^{2+}+2 \mathrm{GSH} \longrightarrow \mathrm{Sr}^{2+}+2 \mathrm{H}^{+}+\mathrm{GSSG}
\end{gathered}
$$

\section{Conclusion}

In the above experiments, glutathione was exposed to different concentration of strontium nitrate and the main interest was to observe the effect of strontium nitrate on the chemical status of glutathione in aqueous media. When glutathione was exposed to different dilutions of strontium nitrate in aqueous media, there was significant decrease in the concentration of reduced glutathione. In means that strontium nitrate causes an increase reduction in reduced form of glutathione and converts this multi functional bio thiol molecule to its oxidized or disulfide form. During this study time dependent effect of different concentrations of strontium nitrate on the chemical status of glutathione was also observed and it was found that there was gradual depletion of reduced glutathione i.e., GSH as the time passed from 0-120 min. The decrease becomes more significant particularly after $1 \mathrm{~h}$ exposure to the action of strontium nitrate. It means that strontium nitrate plays important role in the conversion of reduced (GSH) to its disulfide form (GSSG) or Sr-SG complex. Similarly during this study the interaction of strontium nitrate and glutathione at various $\mathrm{pH}$ was also observed and results showed that strontium nitrate causes maximum decrease in GSH level at a $\mathrm{pH}$ of 7.5. The effect of temperature on the chemical status of GSH was also studied and result revealed that at a temperature of $35^{\circ} \mathrm{C}$ a maximum reaction takes place between strontium nitrate and glutathione, due to which a sufficient decrease in glutathione level occur.

\section{REFERENCES}

1. B.M. Lomaestro and M. Malone, Ann. Pharmacother., 29, 1263 (1995).

2. C. Cereser, J. Guichard, J. Drai, E. Bannier, I. Garcia, S. Boget, P. Parvaz and A. Revol, J. Chromatogr. B, 752, 123 (2001).

3. T.P. Dalton, H.G. Shertzer and A. Puga, Ann. Rev. Pharmacol. Toxicol., 39, 67 (1999)

4. K. Ogawa, Antiox Redox Signaling, 7, 973 (2005).

5. A. Meister and M.E. Anderson, Ann. Rev. Biochem., 52, 711 (1983).

6. H. Khan, S.J. Jan, Hashmatullah, M.F. Khan, K.A. Khan, Asim-urRehman and A. Wahab, Pak. J. Pharm. Sci., 23, 188 (2010).

7. G.K. Balendiran, R. Dabur and D. Fraser, Cell Biochem. Funct., 22, 343 (2004)

8. J. Vitecek, J. Petrlova, J. Petrek, V. Adam, D. Potesil, L. Havel, R. Mikelova, L. Trnkova and R. Kizek, Electrochim. Acta, 51, 5087 (2006).

9. S.J.S. Flora, G. Flora and G. Saxena, In eds.: S.B. Cascas and J. Sordo, Environmental Occurrence, Health Effects and Management of Lead Poisoning, Lead Chemistry, Analytical Aspects, Environmental Impacts and Health Effects, Netherlands: Elsevier Publication, pp. 158-228 (2006).

10. G.L. Ellman, Arch. Biochem. Biophys., 82, 70 (1959).

11. A. Pastore, F. Piemonte, M. Locatelli, A.L. Russo, L.M. Gaeta, G. Tozzi and G. Federici, Clin. Chem., 47, 1467 (2003).

12. H. Khan, M.F. Khan, A.U. Rehman and N. Ullah, Pak. J. Pharm. Sci., 24, 123 (2011).

13. B.P. Ketchel, C.A. Heid, G.L. Wood, M.J. Miller, A.G. Mott, R.J. Anderson and G.J. Salamo, Appl. Optics, 38, 6159 (1999).

14. P.J. Meunier, C. Roux and E. Seeman, New Engl. J. Med., 350, 459 (2004).

15. H. Zahi, Pubmed., 42, 98 (2000).

16. M.E.J. Curzon, Biol. Trace Elem. Res., 3, 309 (1981).

17. R. Lide David, CRC Hand Book of Chemistry and Physics, CRC Press: Boca Raton FL, edn. 83, pp. 439-496 (2002).

18. H. Khan, M.F. Khan, R.Z. Paracha and U. Hashmat, Gomal Univ. J. Res., 26, 1 ( 2010).

19. I. Fabrik, J. Kukacka, J. Baloun, I. Sotornik, V. Adam, R. Prusa, D. Vajtr, P. Babula and R. Kizek, Electroanalysis, 21, 650 (2009). 